\title{
REDESCRIPTION OF MEXECHELES VIRGINIENSIS MALE (ACARIFORMES: CHEYLETIDAE) FROM THE EUROPEAN PART OF RUSSIA
}

\author{
Aleksandra V. Diumina ${ }^{1^{*}}$ and Vladimir V. Abramov ${ }^{2}$ \\ ${ }^{1}$ Russian Academy of Sciences, Zoological Institute, St. Petersburg, Russia \\ ${ }^{2}$ Independent Researcher; Suvorov, Tula Region, Russia \\ *corresponding author; e-mail: d_alexia@mail.ru
}

ABSTRACT: The male of Mexecheles virginiensis (Baker, 1949) (Acariformes; Cheyletidae) found in galleries of scolytine beetles (Coleoptera: Curculionidae) is recorded for the first time in Russia (Tula Region) and redescribed.

KEY WORDS: Acari, Cheyletidae, systematics, Mexecheles virginiensis.

DOI: 10.21684/0132-8077-2018-26-2-213-217

\section{INTRODUCTION}

The family Cheyletidae (Acariformes: Prostigmata) includes over 440 species in 75 genera (Zhang et al. 2011). Most members of this family are predators, but some genera are permanent ectoparasites of small mammals and birds (Volgin 1969; Summers and Price 1970; Bochkov and Fain 2001; Bochkov 2004, 2009). The genus Mexecheles De Leon, 1962 currently includes ten species represented by free-living predators and those ecologically associated with scolytine beetle galleries (Coleoptera: Curculionidae) (De Leon 1962; Volgin 1969; Smiley and Mooser 1970; Faungarworn and Lekprayoon 2010). The latter work provides a key to females of all presently known species. The currently known Mexecheles species, males, were often described for only four species: Mexecheles votandinii (Jeffrey, 1975) in Scotland; M. shiva (Bochkov et Ochoa, 2005) and M. virginiensis (Baker, 1949) in India; and $M$. thailandensis Faungarworn et Lekprayoon, 2010 in Thailand (Jeffrey 1975; Fain and Bochkov 2001; Bochkov and Ochoa 2005; Faungarworn and Lekprayoon 2010).

The fauna of cheyletids in the Suvorov District of the Tula Region, Russia was recently studied by Bochkov and Abramov (2016). Among seven cheyletid mites found in that locality, females of Mexecheles virginiensis were recorded in the territory of Russia for the first time. This species was originally described from females in Virginia, USA (Baker 1949). Males were described much later based on the material from Kashmir, India (Fain and Bochkov 2001). In the present work, we provide a redescrition of $M$. virginiensis males, based on a newly collected material in the European part of Russia.

\section{MATERIAL AND METHODS}

The specimens, used for redescription, were collected near the city of Suvorov (Tula Region,
Russia) by V.V. Abramov in 2016. Extraction from samples was made with Berlese's funnel; mites were stored in tubes with $70 \%$ ethanol, and then were mounted in Hoyer's medium. Drawings were made with a Leica microscope, equipped with a camera lucida and DIC optics. The description of idiosomal setation follows that of Grandjean (1939), as adapted for Prostigmata by Kethley (1990). The nomenclature of leg setae follows that of Grandjean (1944). The description follows modern standards proposed in the recent works on Mexecheles and related cheyletids (Fain and Bochkov 2001; Bochkov and Ochoa 2005; Faungarworn and Lekprayoon 2010). All measurements are in micrometres $(\mu \mathrm{m})$. Mite specimens are deposited at the Zoological Institute of the Russian Academy of Sciences (ZISP), St. Petersburg, Russia.

\section{SYSTEMATICS}

Family Cheyletidae Leach, 1815

Genus Mexecheles De Leon, 1862

Mexecheles virginiensis (Baker, 1949)

(Figs. 1, 2)

Cheyletia virginiensis Baker, 1949: 299, pl. 13, Fig. 95-98.

Paracheyletia virginiensis, Volgin 1955: 169.

Acarocheyla virginiensis, Smiley and Moser 1970: 229-236.

Mexecheles virginiensis, Volgin 1969: 187, Fig. 190-192; Summers and Price 1970: 47, Fig. 39; Fain and Bochkov 2001: 54, Fig. 5.

Material examined. 4 males (AVB 17-110269) from galleries of supposedly Pitiophtorus micrographus (Linnaeus) (Curculionidae: Scolytinae) under bark of dead fir tree (Picea sp.), Russia, Tula Region, Suvorov District, 547'20" N, 36 29'47" E, 


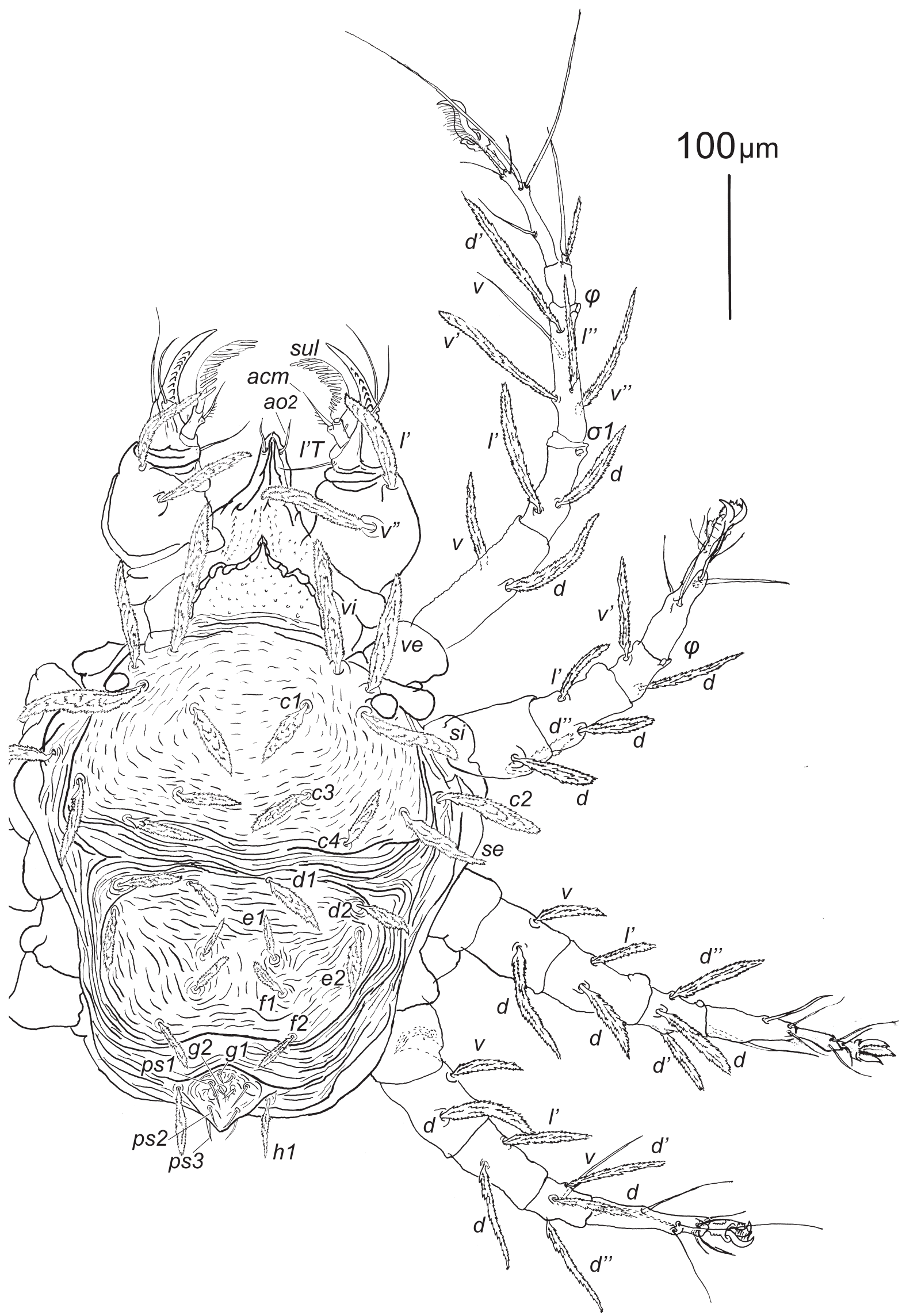

Fig. 1. Mexecheles virginiensis, dorsal view. 


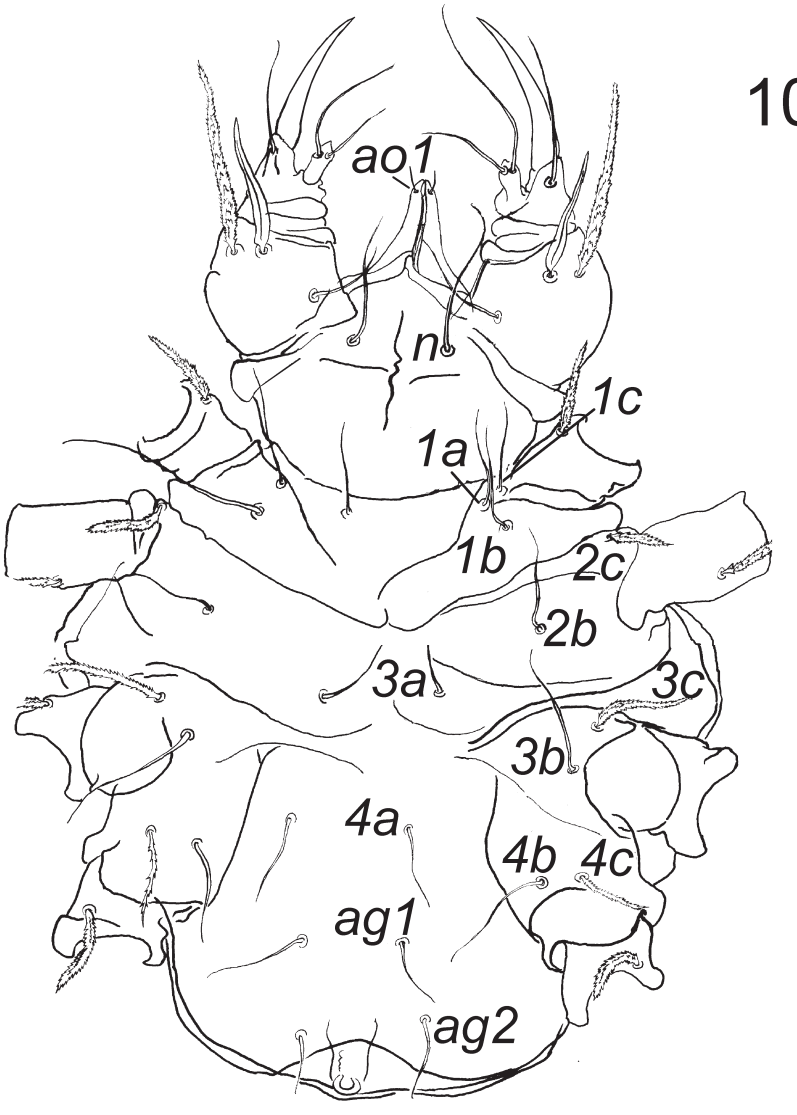

$100 \mu \mathrm{m}$
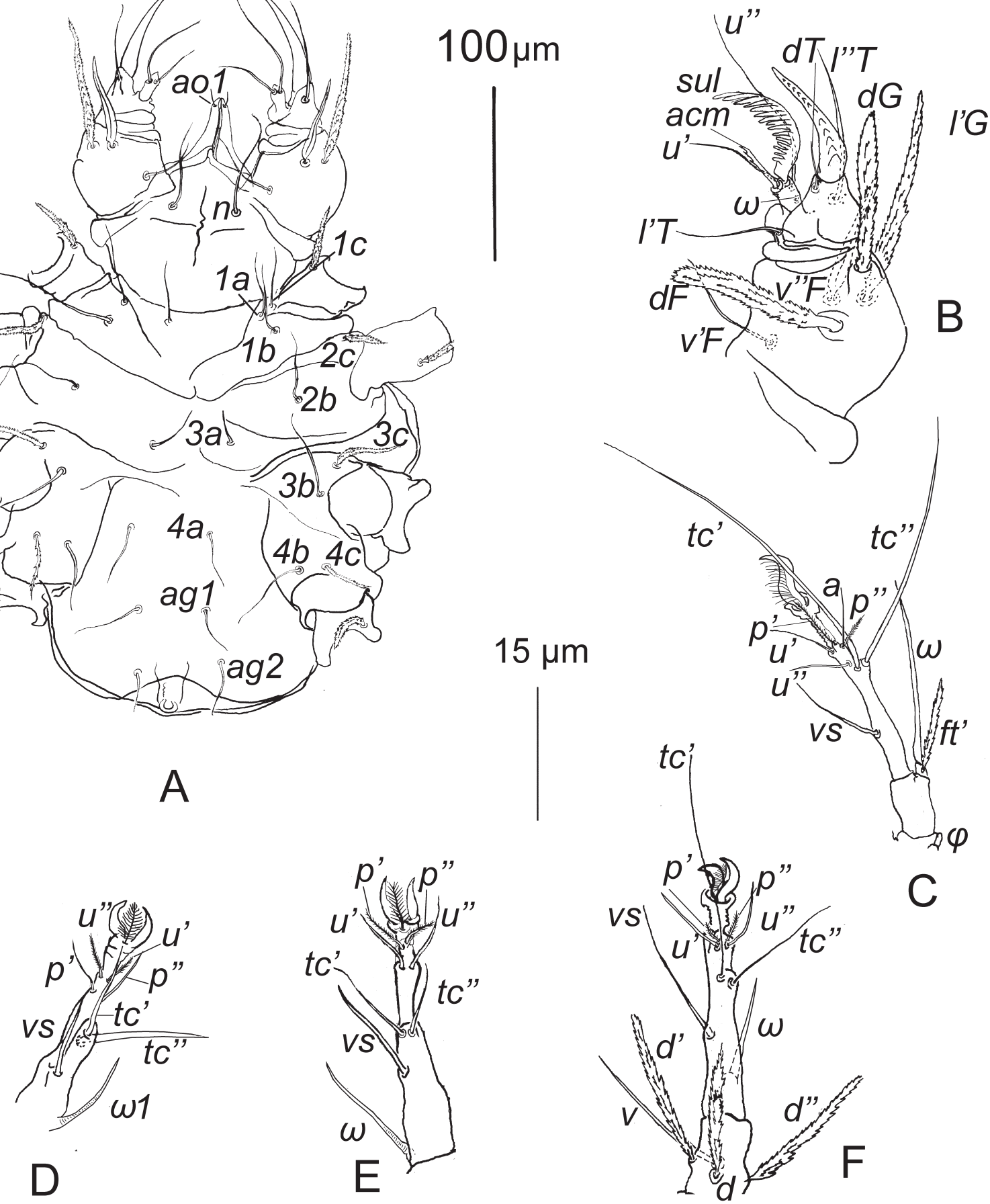

Fig. 2. Mexecheles virginiensis. A—ventral view of idiosoma and gnathosoma, B-dorsal view of palp, $\mathrm{C}-\mathrm{D}-\mathrm{dorsal}$ view of tarsi I-IV, respectively.

October 2016, coll. V.V. Abramov. All material is deposited in ZISP.

Description. Male (range for 4 specimens). Body including rostral extension of gnathosoma: 425-520 long, 410-480 wide. Gnathosoma 165170 long and 175-190 wide. Palpal femur: 100-130 long; setae $d F$ and $v$ " $F$ serrate, 60-75 long, 10-12 wide, seta $v ' F$ smooth filiform. Palpal genu: setae $d G$ and $l$ " $G$ serrate, $70-85$ long and 10-12 wide. Palpal tibia: claw with 10-12 basal teeth, setae $d T$, l'T, l' $T$ smooth filiform. Palpal tarsus: eupathidium sul with 14-15 tines, eupathidium acm with 2-5 fine basal tines, solenidion $\omega$ small stick-like, setae $u^{\prime}, u$ " smooth filiform (Fig. 2B). Peritremes shaped as wide arch with small acute apex (roughly as onion dome), each with 8 chambers. Rostral shield 
weakly ornamented with fine punctures. Idiosoma 300-355 long. Propodonatal shield 150-190 long, with 8 pairs of setae (Fig. 1). All propodontal setae narrowly lanceolate and serrate, $10-12$ wide; length of setae: vi 55-100, ve 80-105, si 55-100, se 75105, c1 30-55, c2 35-50, c3 30-50, and c4 45-80. Hysterosomal shield 125-140 long, with 6 pairs or lanceolate serrate setae 10-12 wide; length of these setae: $d 1$ 30-35, $d 2$ 30-55, e2 30-50, el 30-50, fl $20-30$, and $f 235-40$. Setae $e l$ inserted posterior to level of setae $e 2$. Pseudanal setae $p s 1-p s 3$ present, narrowly lanceolate; seta $p s 2$ with subapical tine. Genital setae $g 1$ and $g 2$ rod-like, about 5 and 7 long, respectively. 2 pairs of filiform agential setae ag present. Aedeagus about 20-28 long.

Tarsi I-IV with solenidion $\omega 1$; length and position of this solenidia: on tarsus I 90-105, situated dorsally; on tarsus II 40-45 long, situated ventrally; on tarsus III 30-40, situated ventrally, on tarsus IV 50-60, situated ventrally (Fig. 2C-F). Claws of all tarsi without basal angle. Solenidia $\varphi$ of tibia I and II shaped as short sticks, about 5 long; solenidion $\sigma 1$ of genu I rudimentary, shaped as minute button. Length of legs I 405-475; length of tarsi: I-100-130, II-75-95, III-75-100, IV90-105.

Remarks. Among previously described species for which males are known, Mexecheles virginiensis is most similar to $M$. thailandensis and M. votandinii (Jeffrey 1975; Faungarworn and Lekprayoon 2010). In males of these species, all dorsal idiosomal setae are narrowly lanceolate or spatuliform and densely serrate. In M. shiva, these setae are rod-like and sparsely serrate. Males of $M$. virginiensis are distinguished by the form of their peritremes; they form an acute anterior angle, i.e., they are shaped like an onion dome (vs. trapezoid-shaped in $M$. thailandensis and rounded in $M$. votandinii). It is necessary to note that male specimens of $M$. virginiensis described herein are noticeably smaller than those described from India (Fain and Bochkov 2001). The body length of European specimens is 425-520 (vs. 570 in the Indian specimen) and the gnatasoma is punctured dorsally (vs. ornamented with short irregular dashes).

Distribution. This species was originally described from the USA, Virginia (Baker 1949). Later on, it was recorded in a number of localities of the New World: USA (Alabama, Louisiana, Mississippi, Nevada and Utah), Canada and Honduras (Smiley and Moser 1970; Summers and Price 1970). In the Old World, it was recorded in Finland
(Penttinen et al. 2013), Russia (Tula Region) (Bochkov and Abramov 2016) and India (Kashmir) (Fain and Bochkov 2001).

\section{ACKNOWLEDGEMENTS}

The authors express their gratitude to late Dr. A.V. Bochkov (Zoological Institute RAS, St. Petersburg, Russia) for his help with the description technique.

\section{REFERENCES}

Baker, E.W. 1949. A review of the mites of the family Cheyletidae in the United States National Museum. Proceedings of the Unites States National Museum, 99: 267-320.

Bochkov, A. V. 2004. [Mites of the family Cheyletidae (Acari: Prostigmata); phylogeny, distribution, evolution and analysis of host-parasite relationships]. Parasitologiya, 38: 122-138. [In Russian]

Bochkov, A.V. 2009. A review of mites of the parvorder Eleutherengona (Acariformes: Prostigmata) - permanent parasites of mammals. Acarina, Supplement: 1-149.

Bochkov, A.V. and Abramov, V.V. 2016. To fauna of the free-living Cheyletidae (Acariformes: Cheyletoidea) of the European part of Russia. Systematic and Applied Acarology, 21 (3): 335-346.

Bochkov, A.V. and Fain, A. 2001. Phylogeny and system of the Cheyletidae (Acari : Prostigmata) with special reference to their host-parasite associations. Bulletin de l'Institut Royal des Sciences Naturelles de Belgique, 71: 5-36.

Bochkov, A.V. and Ochoa, R. 2005. Three new cheyletid species (Acari: Cheyletidae) from the National Museum of Natural History Entomological Collection. Acarina, 12 (2): 137-144.

De Leon, D. 1962. Three new genera and seven new species of cheyletids (Acarina: Cheyletidae). Florida Entomologist, 45 (3): 129-137.

Fain, A. and Bochkov, A.V. 2001. A review of some genera of Cheyletid mites (Acari: Prostigmata) with descriptions of new species. Acarina, 9 (1): 47-95.

Faungarworn, M. and Lekprayoon, C. 2010. Two new species of cheyletid mites (Acari: Prostigmata) from Thailand. Zootaxa, 2494: 59-68.

Grandjean, F. 1939. Les segments postlarvaries de l'hysterosoma chez les oribates (Acarines). Bulletin de la Société Zoologique de France, 64: 273-284.

Grandjean, F. 1944. Observations sur les acaries de la famille des Stigmaeidae. Archives des Sciences Physiques et Naturelles, 26: 103-131.

Jeffrey, I.G. 1975. An undescribed species of Mexecheles (Acarina: Cheyletidae) from a Scottish farm. Acarologia, 17 (4): 668-670. 
Kethley, J. 1990. Acarina: Prostigmata (Actinedida). In: D.L. Dindal (Ed.). Soil Biology Guide. Wiley, New York, 667-756.

Penttinen, R., Viiri, H. and Moser, J. C. 2013. The mites (Acari) associated with bark beetles in the Koli national park in Finland. Acarologia, 53: 3-15.

Smiley, R. L. and Mooser, J. C. 1970. Three cheyletids found with pine bark beetles (Acarina: Cheyletidae). Proceedings of the Entomological Society of Washington, 72: 229-236.

Summers, F. M. and Price, D. W. 1970. Review of the mite family Cheyletidae. University of California Publications in Entomology, 61: 1-153.

Volgin, V.I. 1955. [The family Cheyletidae Leach-predaceous mites]. In: E.N. Pavlovsky (Ed.). Kleshchi
Gryzunov Fauny SSSR. Opredeliteli po Faune SSSR, 59. Academy of Sciences of the USSR, Moscow-Leningrad, pp. 152-176. [In Russian]

Volgin, V. I. 1969. [Mites of the family Cheyletidae of the World]. In: Opredelitely po faune SSSR izdavaemye Zoologicheskim Institutom Akademii Nauk SSSR, 101. Nauka, Leningrad, 432 pp. [In Russian] Zhang, Z.-Q., Fan, Q.-H., Pesic, V., Smith, H., Bochkov, A.V., Khaustov, A.A., Baker, A., Wohltmann, A., Wen, T., Amrine, J.W., Beron, P., Lin, J., Gabrys, G., and Husband, R. 2011. Order Trombidiformes Reuter, 1909. In: Z.-Q. Zhang (Ed.). Animal biodiversity: An outline of higher-level classification and survey of taxonomic richness. Zootaxa, 3148: 129-138. 